\title{
CLINICAL AND THERAPEUTIC CORRELATIONS IN PATIENTS WITH SLIGHT ACUTE PANCREATITIS
}

\author{
Correlações clínico-terapêuticas em pacientes com pancreatite aguda leve
}

Clewis Henri MUNHOZ-FILHO, Fernando BATIGÁLIA, Hamilton Luiz Xavier FUNES

From the Department of Anatomy, São José do Rio Preto Medical School (FAMERP), São José do Rio Preto, São Paulo, Brazil

HEADINGS - Pancreatitis. Epidemiology. Treatment. Surgery.
ABSTRACT - Background: Acute pancreatitis is an inflammatory disease of the pancreas due to enzymatic autodigestion which can cause necrosis or multiple organ failure; its pathophysiology is not fully known yet. Aim: To evaluate the correlation between clinical and therapeutic data in patients with mild acute pancreatitis. Methods: A retrospective study in 55 medical records of patients admitted with acute mild pancreatitis was realized to analyze the association between age, leukocytosis, serum glutamic-oxaloacetic transaminase and lactate dehydrogenase, glucose, antibiotics, time admission and Ranson's scores. Results: There was a positive association between less intensive care (strict hydration, analgesia and monitoring of vital signs), early antibiotic therapy (monotherapy), early return to diet after 48 hours and laboratory control of the serum amylase and lipase (high in the first week and decreasing after 10 days, without any prognostic value). Conclusions: Changes in the management of patients with mild acute pancreatitis, such as enteral nutrition, rational use of lower spectrum antibiotics and intensive care, have contributed significantly to the reduction of hospitalization time and mortality.

\section{Correspondence: \\ Clewis Henri Munhoz Filho \\ E-mail: henri_med@hotmail.com \\ Financial source: none \\ Conflicts of interest: none}

Received for publication: 23/10/2014 Accepted for publication: 08/01/2015

\section{DESCRITORES - Pancreatite.} Epidemiologia. Tratamento. Cirurgia.
RESUMO - Racional: Pancreatite aguda consiste de doença inflamatória do pâncreas por autodigestão enzimática que pode ocasionar necrose ou mesmo falência múltipla de órgãos e de fisiopatologia ainda não totalmente conhecida. Objetivo: Avaliar as correlações existentes entre dados clínicos e terapêuticos em pacientes com pancreatite aguda leve. Métodos: Foi realizado estudo retrospectivo em 55 prontuários de pacientes internados por pancreatite aguda leve para análise de associação entre idade, leucocitose, dosagem sérica de transaminase glutâmico-oxalacética e de desidrogenase lática, glicemia, antibioticoterapia, tempo de internação e escores de Ranson. Resultados: Houve associação positiva entre cuidados intensivos menores (hidratação rigorosa, analgesia e monitorização de sinais vitais), antibioticoterapia precoce (monoterapia), retorno precoce da dieta após 48 horas e controle laboratorial dos níveis séricos de amilase e lipase (elevados na primeira semana e decrescentes após 10 dias, porém sem valor prognóstico). Conclusões: Mudanças no manejo de pacientes com pancreatite aguda leve, tais como nutrição enteral, uso racional de antibióticos de menor espectro e cuidados intensivos têm contribuído significativamente para a redução do tempo de internação e mortalidade.

INTRODUCTION

$T$ he existence of the pancreas comes from ancient Greece, but it was little explored due to its unsuccessful inaccessibility and management ${ }^{12}$. In the early $20^{\text {th }}$ century, Moynihan defined the organ as the most fearsome of the abdominal viscera, emphasizing its morbimortality high rates . $^{4}$

The prevalence of acute pancreatitis ranges from 4.8 to 24.2 cases per 100,000 individuals. About $80 \%$ are related to gallstones and alcoholism, ranging from mild forms (full recovery) to severe forms (potentially fatal) $)^{15}$.

There is no classic signs of acute pancreatitis. It affects, in general, the age group of 30 to 60 years and begins with sudden abdominal pain in the epigastric region and distention accompanied or not by nausea and vomiting ${ }^{13}$. It still presents obscure pathogenesis triggered by a central common phenomenon, the intrapancreatic activation of digestive enzymes, with an unpredictable increase ${ }^{7}$.

In 1974, Ranson proposed a system that allows stratify the severity of the acute pancreatitis ${ }^{11}$. Another model proposed by Balthazar in 1985 considers diagnostic imaging findings with indexation, following the increase severity vizualized by computed tomography ${ }^{1}$.

The diagnosis and management of acute pancreatitis has changed in recent decades, which reinforces the importance of the disease and its forms of stratification and treatment, according to guidelines ${ }^{14}$.

The objective of this study is to evaluate the correlation between clinical and therapeutic data in patients with mild acute pancreatitis in the general surgery service of a charity hospital. 
METHODS

The research study protocol was approved by the Research Ethics Comittee of São José do Rio Preto Medical School (FAMERP) on $06 / 18 / 2013$, under no 16749913.4 .0000 .5415 , without the informed consent term, due to the use of some medical records.

Were evaluated 55 patients' medical records admitted to Lelar Hospital of São José do Rio Preto, São Paulo, Brazil, between 2007 and 2010 with a diagnosis of acute pancreatitis. The following variables were considered: age, leukocytosis, antibiotic therapy, length of hospital stay, serum glutamicoxaloacetic transaminase (SGOT) or aspartate aminotransferase (AST), glucose, amylase, lipase, serum lactate dehydrogenase (SLD) and Ranson scores.

Analysis association was performed by linear regression, Pearson correlation, odds ratio, Fisher's exact test and chi-square test, at a 5\% significance level, by Minitab 12 (State College, PA, USA) and MedCalc 9.3 (MedCalc Inc., Mariakerke, Belgium).

RESULTS

Were used antimicrobials in $74 \%$ of patients; and among them 44\% underwent monotherapy (ciprofloxacin) with significant association in elderly patients from 70 years. There was no significant association between the use of antibiotics and leukocytosis (since most patients maintained levels below $15.000 / \mathrm{mm}^{3}$, with the exception of four patients with leukocytosis above $20.000 / \mathrm{mm}^{3}$, with favorable outcomes. There was no significant association between serum AST and antibiotics because this enzyme levels was less than $300 \mathrm{IU} / \mathrm{l}$ (Figure 1).

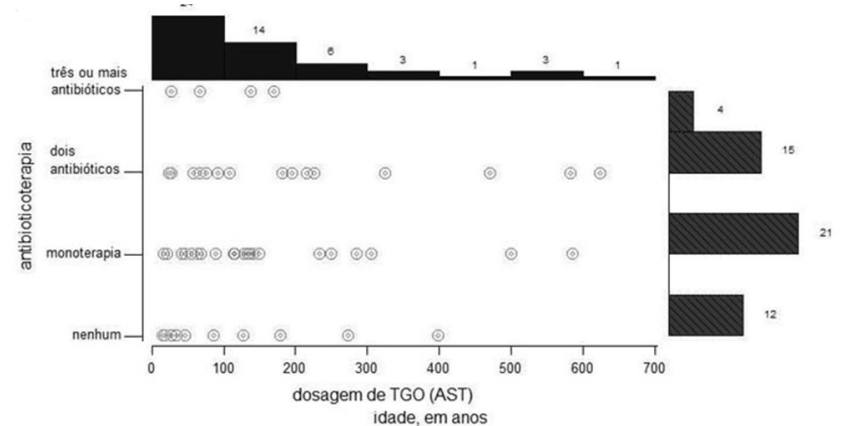

FIGURE 1 - Statistical association between antibiotic therapy and serum aspartate aminotransferase (AST) in acute pancreatitis.

Glucose levels remained below $200 \mathrm{mg} / \mathrm{dl}$ in $90 \%$ of patients (Figure 4), and did not correlated with the use or non-use of antibiotics. There was an association between the use of one or two antibiotics and serum SLD levels less than $600 \mathrm{IU} / \mathrm{L}$ (Figure 2).

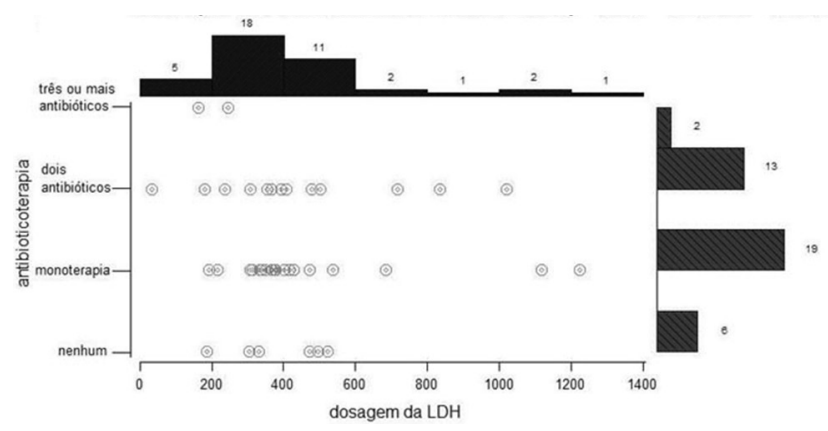

FIGURE 2 - Statistical association between antibiotic therapy and SDL in acute pancreatitis
The length of hospital stay ranged from 1 to 73 days, with the majority of patients hospitalized for less than seven days (Figure 3). Because it is mild acute pancreatitis cases, there was no significant correlation between length of hospital stay and age, leukocytosis and serum AST (Figure 2), glucose or SLD, keeping the patients blood glucose levels below 200 and SLD between 200 and $400 \mathrm{IU} / \mathrm{L}$ (Figure 4).

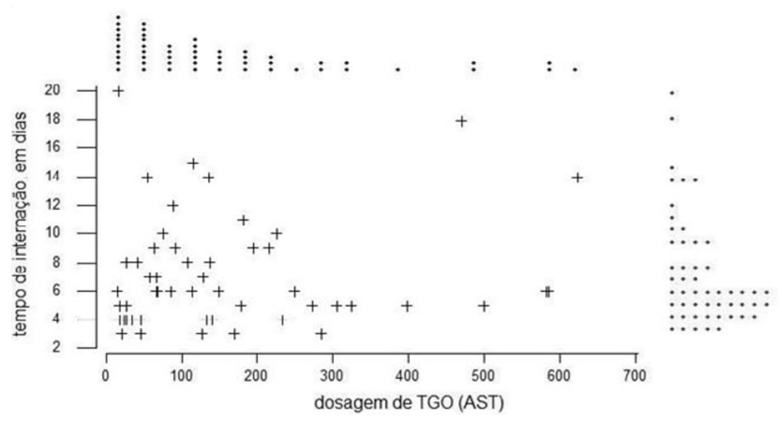

FIGURE 3 - Statistical association between length of hospital stay and serum AST in acute pancreatitis

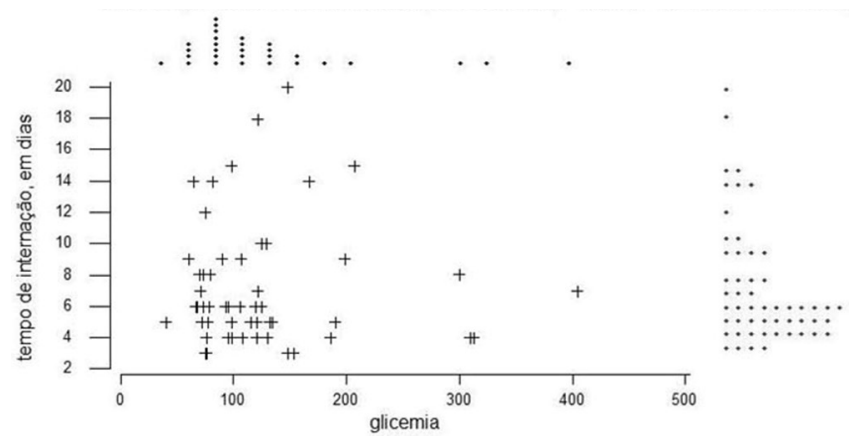

FIGURE 4 - Statistical association between length of hospital stay and glucose in mild acute pancreatitis

Ranson criteria on admission (age $>55 \mathrm{y}$, blood glucose $>200 \mathrm{mg} / \mathrm{dl}, \mathrm{WBC}$ count $>16,000 / \mathrm{mm}^{3}$, SLD $>350 \mathrm{IU} / \mathrm{L}$ and AST $>250 \mathrm{IU} / \mathrm{l}$ ) were applied in $63 \%$ of patients with $57 \%$ of them with only one of these criteria, 34\% with two, $9 \%$ with three criteria and no patient with four or more criteria (Figure 5).

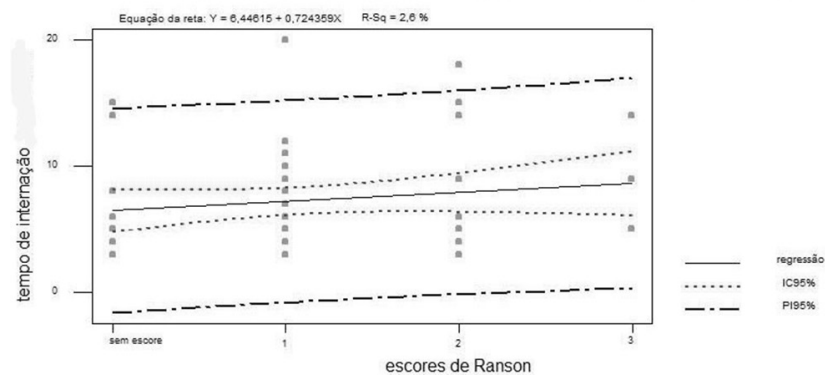

FIGURE 6 - Statistical association between length of hospital stay and Ranson scores in mild acute pancreatitis.

\section{DISCUSSION}

For over a century, pancreatitis has been considered the process of autodigestion of the gland, resulting in premature activation of pancreatic enzymes. However, the pathophysiological mechanisms that affect this phenomenon are not well known. The pathogenesis of acute pancreatitis itself remains under investigation, although the literature indicates multiple predisposing conditions ${ }^{7}$. 

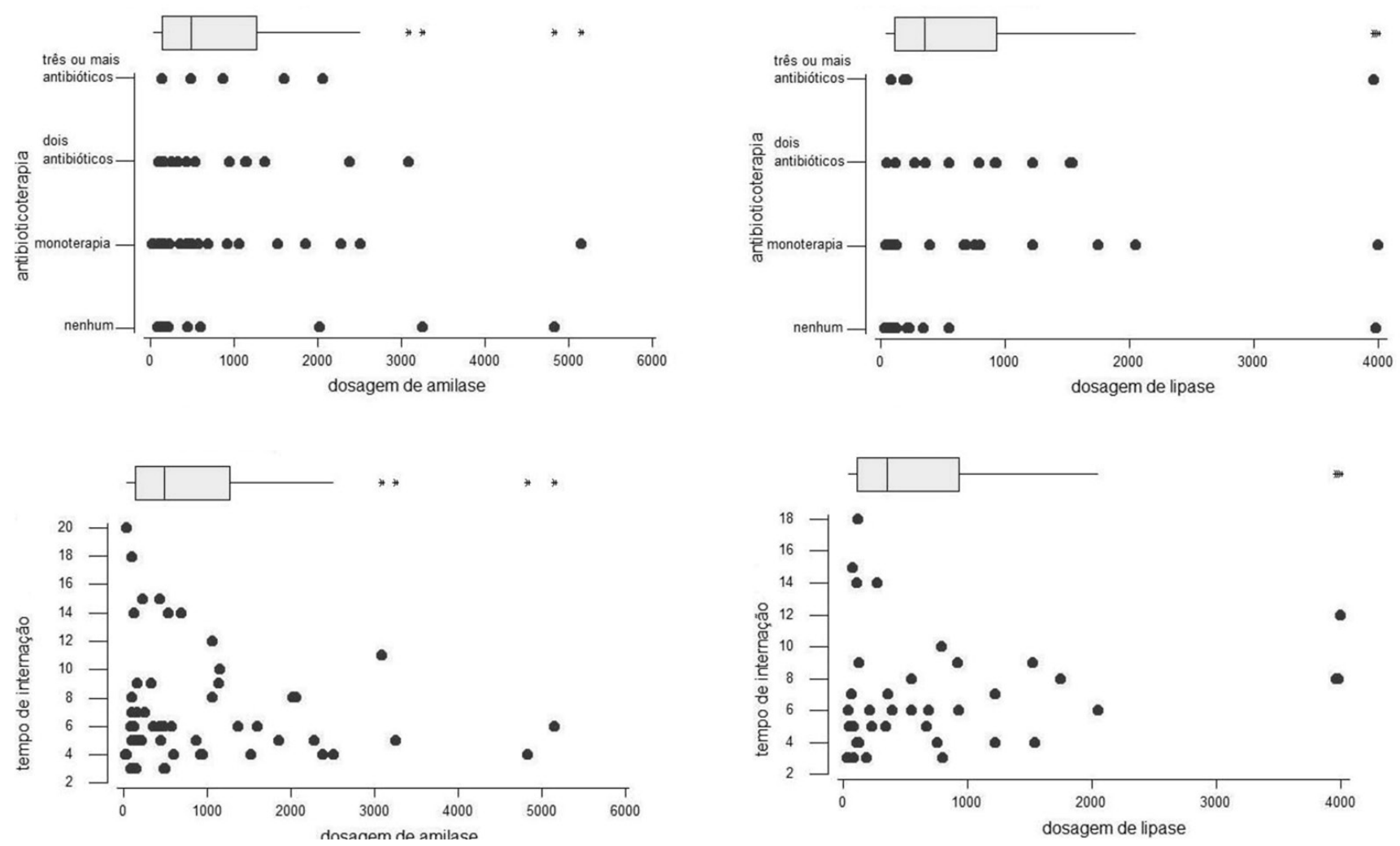

FIGURE 5 - Statistical association between antibiotic therapy and hospitalization time with serum amylase and lipase in mild acute pancreatitis

There is evidence that the central molecular process is the conversion of trypsinogen to trypsin (within the pancreatic acinar cells) in sufficient amounts to exceed the normal defense mechanisms, which leads to a cascade of local inflammation ${ }^{12}$ of systemic inflammatory response during which occurs multiple organs failure and death ${ }^{3}$.

Acute pancreatitis is a broad spectrum disease ${ }^{5}$. There are scientifically validated severity scales, which should be used to support the clinical approach and tailor therapy for each individual case $^{12}$. When acute pancreatitis is suspected in patients with acute pain, mainly in the upper abdomen, Japanese guidelines suggest new diagnostic criteria, such as increased levels of pancreatic enzymes and abnormalities found in ultrasonography, computed tomography or magnetic resonance imaging.

When determining the diagnosis of acute pancreatitis, it is crucial to develop rapid treatment strategy through a strict hydration, analgesia and monitoring of vital signs. Santos et al. ${ }^{13}$ showed no correlation between serum levels of pancreatic enzymes and severity of pancreatitis, except where there is high and persistent levels of amylase, which may indicate complications such as abscess and pseudocyst ${ }^{16}$.

Serumamylasehas beenthemostcommonlyusedlaboratory test in acute pancreatitis, and the diagnosis was confirmed when its elevation is three times the upper limit of normality. Several abdominal diseases may develop from increased serum amylase and lipase; for the diagnosis of acute pancreatitis or acute chronic pancreatitis, sensitivity values for serum amylase and lipase are similar; however, the specificity and positive predictive value for serum amylase are slightly larger than for lipase ${ }^{5}$.

The magnitude of elevation of serum amylase has no prognostic value; however, patients with biliary pancreatitis tend to have higher levels than in the case of alcoholism. Serum lipase rises in $87 \%$ of patients with acute pancreatitis, and has values within the normal range in many situations where the amylase is falsely incresead ${ }^{10}$.

In this present study, amylase was detected in $100 \%$ of patients $(>90 \mathrm{IU} / \mathrm{l})$, with oscillating values. Amylase rises in 2-12 h of onset of symptoms and remains high for 3-5

days. Increased lipase and pancreatic amylase isozymes last for more than 10 days, with no persistence of symptoms or complications. In this study, the use of antibiotics (monotherapy or not) was not associated with serum amylase, and there was lower amylase indexes in line with cases of mild pancreatitis; the same occurred in $87 \%$ of patients with lipase levels near or below $1000 \mathrm{IU} / \mathrm{I}$. Regarding the length of hospital stay, patients hospitalized for less than seven days showed elevated levels of amylase and lipase. After 10 days, these levels tended to decrease, with no indication of prognostic value, which further supports the literature data ${ }^{10}$.

Patients with acute pancreatitis diagnosis should, in principle, be hospitalized, with monitoring of the state of consciousness, the respiratory and cardiovascular conditions and urinary output, appropriate fluid replacement and pain control, and then transferred to the intensive care unit due to the ease of management, intervention or treatment ${ }^{8}$.

Edematous pancreatitis represent $80 \%$ to $90 \%$ of acute pancreatitis, and its remission is possible in most patients without special treatment ${ }^{8}$. The necrotizing pancreatitis covers the remaining $10 \%$ to $20 \%$ of cases, with a high mortality rate, since it is accompanied by bacterial infection and need of surgical care or percutaneous drainage ${ }^{8}$. Regarding the use of antibiotics, Yousaf et al. ${ }^{17}$ reported that broad-spectrum antibiotics should be recommended in severe cases of pancreatitis for a short period of time, usually for 5-7 days. There is no consensus over the value of antibiotic prophylaxis, or about the choice of antimicrobial drugs and duration of therapy².

In recent decades, changes in the management of patients with acute pancreatitis, such as enteral nutrition, rational use of lower-spectrum antibiotics and intensive care have contributed to the reduction of hospital stay and global mortality ${ }^{5}$. This study showed correlation between hospitalization time and severity (criteria number), with clinical improvement in short period of hospitalization probably due to the conditions of mild acute pancreatitis. 
Changes in the management of patients with acute pancreatitis, such as enteral nutrition, rational use of lowerspectrum antibiotics and intensive care have significantly contributed to the reduction in length of hospital stay and mortality.

\section{REFERENCES}

1. Balthazar EJ, Ranson JH, Naidich DP, Megibow AJ, Caccavale $\mathrm{R}_{t}$ Cooper MM. Acute pancreatitis: prognostic value of CT. Radiology. 1985 Sep;156(3):767-72.

2. Baron TH, Morgan DE. Current concepts: acute necrotizing pancreatitis. N Eng J Méd 1999;340(18): 1412-17.

3. Carneiro MC, Batista RS. O mosaico patogênico da pancreatite aguda grave. $\mathrm{O}$ mosaico patogênico da pancreatite aguda grave. Rev Col Bras Cir. 2004; 391-397.

4. Corman ML: Traditions, trials, and treatises. Dis Colon Rectum 1999:42(9):1130-1135.

5. De Campos T, Braga CF, Kuryura L, Hebara D, Assef JC, Rasslan $\mathrm{S}$. Changes in the management of patients with severe acute pancreatitis. Arq Gastroenterol 2008; 45(3)181-5.

6. Fukuda JK, Franzon O, Resende-Filho FO, Kruel NK, Ferri TA Prognóstico dos casos de pancreatite aguda pelo escore de PANC 3. Arq Bras Cir Dig. 2013;26(2):133-5.

7. Godinho R. Etiopatogenia da pancreatite aguda. Rev Port Med Int. 1999;6(2)123-33.

8. Hirota M, Takada T, Kitamura N, Ito T, Hirata K, Yoshida M, Mayumi T, Kataoka K, Takeda K, Sekimoto M, Hirota M, Kimura Y, Wada K, Amano H, Gabata T, Arata S, Yokoe M, Kiriyama S. Fundamental and intensive care of acute pancreatitis. J Hepatobiliary Pancreat Sci. 2010 Jan;17(1):45-52.
9. Kiriyama S, Gabata T, Takada T, Hirata K, Yoshida M, Mayumi T, Hirota M, Kadoya M, Yamanouchi E, Hattori T, Takeda K, Kimura Y, Amano H, Wada K, Sekimoto M, Arata S, Yokoe M, Hirota M. New diagnostic criteria of acute pancreatitis. J Hepatobiliary Pancreat Sci. 2010 Jan;17(1):24-36.

10. Pacheco RC, Nishioka SA, Oliveira LCM. Validity of serum amylase and lipase for the differential diagnosis between acute/acutized chronic pancreatitis and other causes of acute abdominal pain. Arq Gastroenterol 2003:40(4):233-238.

11. Ranson JH, Rifkind KM, Roses DF, Fink SD, Eng K, Spencer FC. Prognostic signs and the role of operative management in acute pancreatitis. Surg Gynecol Obstet. 1974 Jul;139(1):69-81.

12. Rosa I, Pais MJ, Fátima C, Queiroz A. Pancreatite aguda: atualização e propostadeprotocolodeabordagem. UnidadedeGastroenterologia do Hospital do Espírito Santo. Évora. Acta Méd Port 2004; 17: 31724.

13. Santos JS, Elias Júnior J, Scarpelini S, Sankarankutty AK. Pancreatite aguda: atualização de conceitos e condutas. Medicina, Ribeirão Preto. 2003;36: 266-282.

14. Sekimoto M, Shikata S, Takada T, Hirata K, Yoshida M, Hirota M, Kitamura N, Shirai K, Kimura Y, Wada K, Amano H, Kiriyama S, Arata S, Gabata T, Hirota M, Takeda K, Yokoe M, Mayumi T. Changes in management of acute pancreatitis before and after the publication of evidence-based practice guidelines in 2003. J Hepatobiliary Pancreat Sci. 2010 Jan;17(1):17-23.

15. Steinberg W, Tenner S. Acute pancreatitis. N Engl J Med. 1994 Apr 28;330(17):1198-210.

16. Wada K, Takada T, Hirata K, Mayumi T, Yoshida M, Yokoe M, Kiriyama S, Hirota M, Kimura Y, Takeda K, Arata S, Hirota M, Sekimoto M, Isaji S, Takeyama Y, Gabata T, Kitamura N, Amano H. Treatment strategy for acute pancreatitis. J Hepatobiliary Pancreat Sci. 2010 Jan;17(1):79-86.

17. Yousaf M, McCallion K, Diamond T. Management of severe acute pancreatitis. Br J Surg. 2003 Apr;90(4):407-20. 